\title{
GULMA TEKI-TEKIAN DI KEBUN KELAPA SAWIT DESA MAKMUR JAYA, TIKKE RAYA, KABUPATEN PASANGKAYU
}

\section{SEDGES IN OIL PALM PLANTATION OF MAKMUR JAYA VILLAGE, TIKKE RAYA, PASANGKAYU REGENCY}

\author{
Slamet Mardiyanto Rahayu ${ }^{1 *}$ \\ ${ }^{1}$ Program Studi Biologi, Fakultas MIPA, Universitas Islam Al-Azhar Mataram \\ Jl. Unizar No.20, Turida, Kec. Sandubaya, 83232 Mataram, Nusa Tenggara Barat Indonesia
}

\begin{abstract}
ABSTRAK
Salah satu daerah yang memiliki kebun kelapa sawit adalah Desa Makmur Jaya, Kecamatan Tikke Raya, Kabupaten Pasangkayu (dulu bernama Kabupaten Mamuju Utara), Provinsi Sulawesi Barat. Salah satu permasalahan dalam budidaya tanaman kelapa sawit adalah gulma. Penelitian ini bertujuan untuk mengetahui jenis gulma teki-tekian di kebun kelapa sawit Desa Makmur Jaya, Kecamatan Tikke Raya, Kabupaten Pasangkayu, Provinsi Sulawesi Barat. Berdasarkan penelitian diperoleh 3 jenis gulma tekitekian di kebun kelapa sawit Desa Makmur Jaya, yaitu Cyperus compressus, C.rotundus, dan Fimbristylis milliacea. Gulma teki-tekian memiliki daun mirip dengan gulma berdaun sempit, namun memiliki batang mendong (hanya terdiri dari satu ruas yang panjang) dan juga berbentuk segitiga. Gulma teki-tekian mempunyai senyawa allelopati yang menyebabkan tanaman kelapa sawit sulit tumbuh..
\end{abstract}

Kata kunci: Kelapa Sawit, Desa Makmur Jaya, Teki-tekian

\section{ABSTRACT}

One area that has oil palm plantations is Makmur Jaya Village, Tikke Raya District, Pasangkayu Regency (formerly called North Mamuju Regency), West Sulawesi Province. One of the problems in the cultivation of oil palm is weeds. This study aims to determine the types of puzzle weeds in the oil palm plantation in Makmur Jaya Village, Tikke Raya District, Pasangkayu Regency, West Sulawesi Province. Based on the research, there were 3 types of puzzle weeds in the Makmur Jaya Village oil palm plantation, namely Cyperus compressus, C.rotundus, and Fimbristylis milliacea. Riddle weeds have leaves similar to narrow-leaf weeds, but have a mendong stem (consisting of only one long segment) and are also triangular in shape. Riddle weeds have allelopathic compounds which make it difficult for palm oil plants to grow.

Keywords: Oil Palm, Makmur Jaya Village, Sedges

\section{Pendahuluan}

Kelapa sawit (Elaeis guinensis Jacq.) merupakan tumbuhan tropis yang berasal dari Afrika Barat (Fauzi dkk., 2002). Tanaman ini dapat tumbuh di luar daerah asalnya, termasuk Indonesia. Komoditas kelapa sawit merupakan salah satu sektor penunjang pendapatan dari sektor non migas bagi Indonesia. Permintaan terhadap hasil olahan kelapa sawit khususnya minyak kelapa sawit selalu mengalami peningkatan setiap tahunnya (Adriadi et al., 2012).

\footnotetext{
${ }^{*}$ Penulis Korespondensi.

E-mail: slamet.mardiyantorahayu84@gmail.com Telp: +62-
}

Tingginya pertumbuhan industri kelapa sawit merupakan hal positif yang perlu dipertahankan dan ditingkatkan lagi. Usaha untuk mempertahankan dan meningkatkan produktivitas tanaman dapat dilakukan melalui kegiatan pemeliharaan yang tepat. Salah satu unsur pemeliharaan kebun kelapa sawit pada periode tanaman menghasilkan (TM) adalah pengendalian gulma (Sarjono and Zaman, 2017).

Gulma merupakan tumbuhan yang mengganggu atau merugikan tanaman produktif yang ditanam manusia sehingga para petani berusaha untuk mengendalikannya. Gulma dapat menimbulkan kerugian secara perlahan selama gulma itu berinteraksi dengan tanaman (Sembodo, 2010). Kehadiran gulma di 


\section{Jurnal Agrotech 9 (2) 56-59}

perkebunan kelapa sawit dapat mengakibatkan penurunan kuantitas dan kualitas produksi tandan buah segar (TBS), gangguan terhadap pertumbuhan tanaman, peningkatan serangan hama dan penyakit, gangguan tata guna air, dan secara umum akan meningkatkan peningkatan biaya usaha tani (Pahan, 2006).

Penelitian ini bertujuan untuk mengetahui jenis dan karakteristik gulma teki-tekian di kebun kelapa sawit Desa Makmur Jaya, Kecamatan Tikke Raya, Kabupaten Pasangkayu, Provinsi Sulawesi Barat.

\section{Metode Penelitian}

Penelitian dilakukan di kebun kelapa sawit Desa Makmur Jaya, Kecamatan Tikke Raya, Kabupaten Pasangkayu, provinsi Sulawesi Barat pada 1'21'17'S-119²5'27'E. Alat yang digunakan berupa rollmeter, gunting, tiang patok pancang, parang, penggaris, kalkulator, alat tulis, kamera, Global Positioning System (GPS), dan pisau cutter. Adapun bahan yang digunakan berupa tali raffia dan kantong plastik.

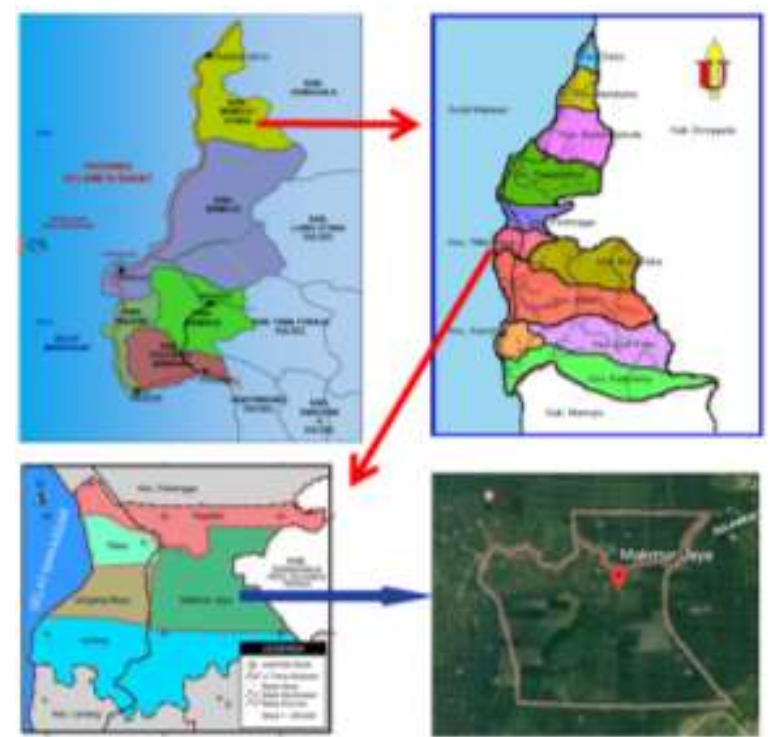

Gambar 1. Lokasi Penelitian di Kebun Kelapa Sawit Desa Makmur Jaya, Kecamatan Tikke Raya, Kabupaten Pasangkayu, Provinsi Sulawesi Barat

Penelitian dilakukan dengan metode survey dan teknik pencuplikan sampel secara purposive sampling. Sampel diambil pada kebun tanaman kelapa sawit yang berumur 5-7 tahun dengan membuat plot berukuran $1 \times 1 \mathrm{~m}$ dengan 10 kali ulangan. Gulma yang ditemukan dicatat jenisnya dan dihitung. Identifikasi jenis gulma mengacu pada Sembodo (2010) dan Barus (2003). Analisis data dilakukan secara deskriptif
e-ISSN : 2621-7236

p-ISSN : 1858-134X

mengenai jenis dan karakteristik gulma tekitekian di kebun kelapa sawit Desa Makmur Jaya, Kecamatan Tikke Raya, Kabupaten Pasangkayu, Provinsi Sulawesi Barat.

\section{Hasil dan Pembahasan}

Berdasarkan penelitian diperoleh sebanyak 3 (tiga) jenis gulma teki-tekian di kebun kelapa sawit Desa Makmur Jaya, Kecamatan Tikke Raya, Kabupaten Pasangkayu, Provinsi Sulawesi Barat.

Tabel 1. Gulma Teki-Tekian di Kebun Kelapa Sawit Desa Makmur Jaya

\begin{tabular}{lll}
\hline No & Nama & Jumlah Individu \\
\hline 1 & Cyperus compressus & 190 \\
2 & Cyperus rotundus & 289 \\
3 & Fimbristylis milliacea & 178 \\
\hline
\end{tabular}

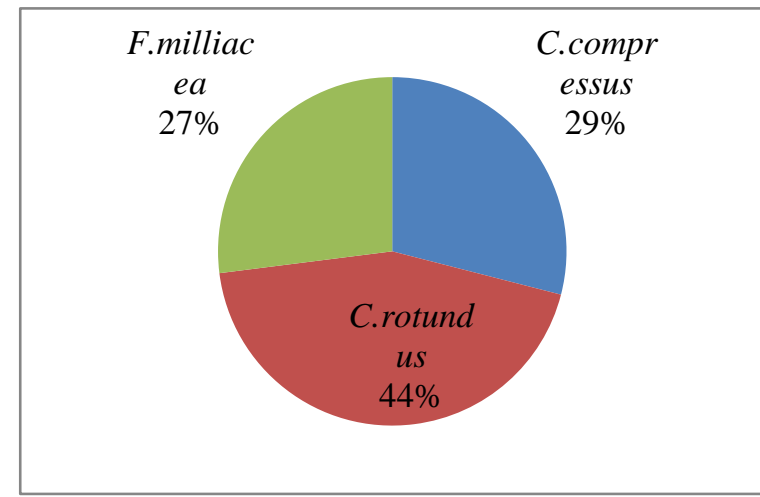

Gambar 2. Persentase Gulma Teki-Tekian di Kebun Kelapa Sawit Desa Makmur Jaya, Kecamatan Tikke Raya, Kabupaten Pasangkayu

Gulma teki-tekian merupakan Familia Cyperaceae dengan karakteristik: memiliki daun mirip dengan gulma berdaun sempit, namun memiliki batang mendong (hanya terdiri dari satu ruas yang panjang) dan juga berbentuk segitiga. Gulma teki mempunyai senyawa allelopati yang menyebabkan tanaman budidaya sulit tumbuh (Siregar dkk., 2017).

Berikut merupakan karakteristik jenis gulma teki-tekian di kebun kelapa sawit Desa Makmur Jaya, Kecamatan Tikke Raya, Kabupaten Pasangkayu, Provinsi Sulawesi Barat.

\section{Cyperus compressus}

C.compressus merupakan gulma yang tingginya 10-95 cm. Batang berbentuk segitiga (triangularis) dan tajam. Daunnya berjumlah 4-10 helai yang terkumpul pada pangkal batang. Akar dengan pelepah daunnya tertutup tanah. Helaian daun berbentuk pita bersilang sejajar, permukaan 


\section{Jurnal Agrotech 9 (2) 56-59}

atas berwarna hijau mengkilat dengan panjang daun 10-30 $\mathrm{cm}$ dan lebar 3-6 cm. C.compressus memiliki alelopati yang mampu membunuh tumbuhan lainnya.

\section{Cyperus rotundus}

Cyperus rotundus merupakan gulma tahunan berkembang biak dengan biji dan umbi akar, tumbuh tegak, berbentuk segitiga, tingginya $10-50 \mathrm{~cm}$ dan penampangnya $1-2 \mathrm{~mm}$. Permukaan daun berwarna hijau tua dan permukaan daun bawah hijau muda, lebar daun 2 6 mm. Bunga $C$. rotundus memiliki bulir tunggal, berwama cokelat, satu bulir berbunga sepuluh sampai empat puluh. Sistem perakaran C. rotundus serabut dengan rambut-rambut halus, akar memiliki banyak anak cabang akar yang menyebar (Moenandir, 1993). C. rotundus gulma tahunan bereproduksi secara vegetatif dengan stolon dan rhizome yang mampu bertahan didalam tanah dan akan tumbuh kembali jika kondisi memungkinkan untuk tumbuh.(Ilham, 2014).

\section{Fimbristylis milliacea}

F.milliacea merupakan tumbuhan setahun, tumbuh berumpun, dengan tinggi $20-60 \mathrm{~cm}$. Batangnya ramping, tidak berbulu-bulu, bersegi empat, dan tumbuh tegak. Daunnya terdapat di bagian pangkal, bentuk bergaris, menyebar lateral, tepi luar tipis, panjang sampai $40 \mathrm{~cm}$. Bunganya berkarang dan bercabang banyak. Anak bulir kecil dan banyak sekali, warna cokelat dengan punggung berwarna hijau, bentuk bola sampai jorong, dengan ukuran $2-5 \mathrm{~mm} \mathrm{x}$ $1,5-2 \mathrm{~mm}$. Buahnya berwarna kuning pucat atau hampir putih, bentuk bulat telur terbalik

C.rotundus merupakan gulma teki-tekian yang paling banyak terdapat di kebun kelapa sawit Desa Makmur Jaya, Kecamatan Tikke Raya, Kabupaten Pasangkayu. Hal ini karena allelopati dari $C$. rotundus tidak hanya menekan pertumbuhan dan produksi tanaman pangan, tapi juga dapat menekan pertumbuhan gulma lain. Saputra (2012) menyatakan bahwa biomassa teki (C. rotundus) dapat digunakan untuk menekan pertumbuhan gulma daun lebar. Ekstrak $C$. rotundus dapat menekan perkecambahan beberapa gulma berdaun lebar dengan berbagai konsentrasi pada skala laboratorium (Delsi, 2012).

Alelopati merupakan senyawa kimia yang dihasilkan oleh tumbuhtumbuhan baik sewaktu masih hidup atau setelah mati (Moenandir, 1993).
e-ISSN : 2621-7236

p-ISSN : 1858-134X

Terdapat dua jenis alelopati yang terjadi di alam, yaitu alelopati yang sebenarnya dan alelopati fungsional. Alelopati yang sebenarnya adalah pelepasan senyawa beracun dari tumbuhan ke lingkungan sekitarnya dalam bentuk senyawa aslinya yang dihasilkan. Sedangkan alelopati fungsional ialah pelepasan senyawa kimia ke lingkungan yang telah mengalami perubahan akibat mikroba tanah. Senyawa-senyawa alelopati dapat dilepaskan dari jaringan tubuh tumbuhan dalam berbagai cara termasuk melalui penguapan, eksudat akar, pencucian, dan pembusukan bagian-bagian organ yang mati (Sastroutomo, 1990).

\section{Kesimpulan}

Berdasarkan penelitian diperoleh 3 jenis gulma teki-tekian di kebun kelapa sawit Desa Makmur Jaya, yaitu Cyperus compressus, C.rotundus, dan Fimbristylis milliacea. Gulma teki-tekian memiliki daun mirip dengan gulma berdaun sempit, namun memiliki batang mendong (hanya terdiri dari satu ruas yang panjang) dan juga berbentuk segitiga. Gulma teki mempunyai senyawa allelopati yang menyebabkan tanaman kelapa sawit sulit tumbuh.

\section{Daftar Pustaka}

Adriadi, A., Chairul, and Solfiyeni. (2012). Vegetation analysis of weed in palm oil plantation (Elaeis quineensis Jacq.) in Kilangan, Muaro Bulian, Batang Hari. Jurnal Biologi Universitas Andalas 1 (2): 108-115.

Barus, E. (2003). Pengendalian Gulma di Perkebunan. Yogyakarta: Kanisius.

Delsi, Y. (2012). Studi Potensi Allelopati Teki (Cyperus rotundus L.) sebagai Herbisida untuk Pengendalian Gulma Berdaun Lebar. Tesis. Bogor: Institut Pertanian Bogor.

Fauzi, Y., Widyastuti, Y.E., Setyawibawa, I., dan R. Hartono. (2002). Kelapa Sawit: Budidaya,

Pemanfaatan Hasil Limbah, Analisa Usaha, dan Pemasaran. Jakarta: Penebar Swadaya.

Ilham, J. (2014). Identifikasi dan Distribusi Gulma di Lahan Pasir Pantai Samas, Kabupaten Bantul, Daerah Istimewa Yogyakarta. Planta Tropika Journal of Agro Science 2 (2): 90-98. 
Jurnal Agrotech 9 (2) 56-59

Moenandir, J. (1993). Ilmu Gulma Dalam sistem Pertanian Dalam Sistem Pertanian. Jakarta: Raja Grafindo Persada.

Pahan, I. (2006). Panduan Lengkap Kelapa Sawit: Manajemen Agribisnis dari Hulu hingga

Hilir. Jakarta: Penebar Swadaya.

Sarjono, B.Y. and S. Zaman. (2017). Weed Control of Oil Palm Plantation (Elaeis guineensis Jacq.) in Bangun Koling Estate. Buletin Agrohortikultura 5 (3): $384-391$.

Saputra, R. (2012). Pemanfaatan biomasa teki (Cyperus rotundus L.) untuk pengendalian

gulma berdaun lebar pada pertanaman kedelai (Glycine $\max ($ L.) Merr.) Skripsi. Bogor: Institut Pertanian Bogor.
e-ISSN : 2621-7236

p-ISSN : 1858-134X

Sastroutomo, S.S.(1990). Ekologi Gulma. Jakarta: Gramedia Pustaka Utama.

Sembodo, D.R.J. (2010). Gulma dan Pengelolaannya. Yogyakarta: Graha Ilmu.

Siregar, E.N., Nugroho, A., dan R. Sulistyono. (2017). Uji Alelopati Ekstrak Umbi Teki Pada Gulma Bayam Duri (Amaranthus spinosus L.) dan Pertumbuhan Tanaman Jagung Manis (Zea mays L. Saccharata). Jurnal Produksi Tanaman 5 (2): 290-298.

Hubbart, S., S. Peng, P. Horton, Y. Chen, and E.H. Murchie. 2007. Trends in leaf photosynthesis in historical rice varieties developed in the Philippines since 1966. J. Exp. Bot. (10): 1083-1093. 